\title{
First report of strawberry crinivirus 3 and strawberry crinivirus 4 in strawberry in Iran
}

\author{
Mohammad Hajizadeh $^{1}$ (D) Nasrin Ghaderi Zandan ${ }^{1} \cdot$ Zahra Kashiha $^{1} \cdot$ Igor Koloniuk $^{2}$
}

Received: 6 December 2021 / Accepted: 7 January 2022 / Published online: 13 January 2022

(c) The Author(s) under exclusive licence to Società Italiana di Patologia Vegetale (S.I.Pa.V.) 2022

Keywords SCrV-3 $\cdot \mathrm{SCrV}-4 \cdot \mathrm{RT}-\mathrm{PCR} \cdot$ Strawberry $\cdot$ Viral disease

In Iran, strawberry (Fragaria $\times$ ananassa) is grown in two main regions in the west (Kurdistan Province) and north (Mazandaran, Guilan and Golestan Provinces) of the country. Criniviruses emerged as a major agricultural threat worldwide among strawberries. To monitor two criniviruses, strawberry crinivirus 3 (SCrV-3) and strawberry crinivirus 4 (SCrV-4), 23 strawberry plants showing virus-like symptoms were collected from commercial fields in the west and north of Iran and subjected to RT-PCR. Total RNA was extracted using a silica-capture method, cDNA was synthesized and PCRs were conducted using SCrV3mF (5'- TTG TCATAAGGAGGCACAGC - $3^{\prime}$ ) and SCrV3mR (5'- GCT CTTGTCATAGGCACGAA - $3^{\prime}$ ) (this work), and SCrV4f1 (5'- CCAATTCTGATCCTATCCTTAGT -3') (Chen et al. 2018) and SCrV4mR1 (5'- AGGCGCGAAATCCAAACT TC $-3^{\prime}$ ) (this work) designed from conserved partial virus sequences available in GenBank. Expected RT-PCR products of $\sim 673$ bp and $\sim 1362$ bp in size were obtained from 11 and four samples for SCrV-3 and SCrV-4, respectively, and sequenced. SCrV-3 was detected in samples from both regions, whereas $\mathrm{SCrV}-4$ was detected only from western Iran, suggesting that SCrV-4 may not be evenly distributed in Iran. Nucleotide BLAST analysis confirmed that the two sequences belonged to $\mathrm{SCrV}-3$ and $\mathrm{SCrV}-4$ and were submitted to GenBank as accession numbers OL631153 and MZ868643, respectively. The SCrV-3 sequence shared $98.6 \%$ nucleotide identity with the 1 a coding region of

Mohammad Hajizadeh

m.hajizadeh@uok.ac.ir

1 Department of Plant Protection, Faculty of Agriculture, University of Kurdistan, Sanandaj, Iran

2 Department of Plant Virology, Institute of Plant Molecular Biology, Biology Centre, Czech Academy of Sciences, 37005 Ceske Budejovice, Czech Republic isolate M1 of SCrV-3 (EU267168) from Maryland, USA. The Iranian SCrV-4 isolate shared $82.4 \%$ nucleotide sequence identity with the 1 a coding region of isolate B1156-M3 of SCrV-4 (EU490423) from Maryland, USA. Both SCrV-3 and SCrV-4 have been reported so far in North America (Ding et al. 2016; Diaz-Lara et al. 2021) and China (Chen et al. 2018). To our knowledge, this is the first report of SCrV-3 and SCrV-4 infecting strawberry in Iran.

Funding No funding was received for conducting this study.

\section{Declarations}

Ethical approval This article does not contain any studies with human participants or animals performed by the author.

Conflict of interest The authors declare that there is no conflict of interest.

\section{References}

Chen D, Ding X, Wang A, Zhang J, Wu Z (2018) First report of strawberry crinivirus 3 and strawberry crinivirus 4 on strawberry in China. New Dis Rep 37:24

Diaz-Lara A, Stevens KA, Klaassen V, Hwang MS, Al Rwahnih M (2021) Sequencing a Strawberry Germplasm Collection Reveals New Viral Genetic Diversity and the Basis for New RT-qPCR Assays. Viruses 13:1442

Ding X, Li Y, Hernández-Sebastià C, Abbasi PA, Fisher P, Celetti MJ, Wang A (2016) First report of strawberry crinivirus 4 on strawberry in Canada. Plant Dis 100:1254

Publisher's Note Springer Nature remains neutral with regard to jurisdictional claims in published maps and institutional affiliations. 